American Journal of Animal and Veterinary Sciences 2 (4): 108-113, 2007

ISSN 1557-4555

(C) 2007 Science Publications

\title{
Nutrient Digestibility and Gas Production of Some Tropical Feeds Used in Ruminant Diets Estimated by the in vivo and in vitro Gas Production Techniques
}

\author{
Paya Hamid, Taghizadeh Akbar, Janmohammadi Hossein and Moghadam Gholam Ali \\ Department of Animal Science, Faculty of Agriculture, University of Tabriz, Iran
}

\begin{abstract}
Some feedstuffs which used in ruminants diet (corn grain, soybean meal, wheat bran and alfalfa) were analyzed for chemical composition, apparent in vivo nutrient digestibility, in vitro fermentation gas production and metabolizable energy. Chemical composition of test feeds differed in nutrient contents. Initially apparent in vivo digestibility of alfalfa nutrients were obtained then digestibility of nutrients for the other test feeds were determined by difference method, using 16 Ghezel mature rams (mean weight of $43.9 \pm 4 \mathrm{~kg}$ ). In vivo DM, CP, NDF and OM apparent digestibility were different among the test feeds $(\mathrm{p}<0.05)$. Regarding to the results, corn grain had a high DM and OM digestibility between test feeds and soybean meal had a high CP and NDF digestibility between test feeds $(\mathrm{p}<0.05)$. Cumulative gas production was recorded at 2, 4, 8, 12, 16, 24, 36, 48, 72 and $96 \mathrm{~h}$ of incubation and the equation of $\mathrm{p}=\mathrm{A}(1-\mathrm{e}-\mathrm{ct})$ was used to describe the kinetics of gas production. Potential gas production $(\mathrm{A})$ and rates of gas production $(\mathrm{c})$ differed $(\mathrm{p}<0.01)$ among feeds. Corn grain showed higher potential gas production (A) $\left(326.5 \mathrm{~mL} \mathrm{~g}^{-1} \mathrm{DM}\right)$ and wheat bran had higher rate of gas production (c) $\left(0.097 \mathrm{~h}^{-1}\right)$ than the other feeds, inverses alfalfa $\left(257.6 \mathrm{~mL} \mathrm{~g}^{-1} \mathrm{DM}\right)$ and corn grain $\left(0.048 \mathrm{~h}^{-1}\right)$ had lower potential gas production and rate of gas production than the other test feeds, respectively. The metabolizable energy $\left(\mathrm{MJ} \mathrm{kg}^{-1} \mathrm{DM}\right)$ content of feeds was calculated using in vivo organic matter digestibility and gas production data. According to in vivo organic matter digestibility data, the ME values ranged from 9.2 in alfalfa to $13.3 \mathrm{MJ} \mathrm{kg}^{-1} \mathrm{DM}$ in corn grain. It was concluded that regarding to different chemical composition of test feeds, the in vivo digestibility, in vitro gas production and ME of feeds showed different values.
\end{abstract}

Key words: Feed evaluation, in vivo digestibility, gas production, metabolizable energy

\section{INTRODUCTION}

The nutritive value of a ruminant feed is determined by the concentrations of its chemical components, as well as their rate and extent of digestion. Determining the digestibility of feeds in vivo is laborious, expensive, requires large quantities of feed and is largely unsuitable for single feedstuffs thereby making it unsuitable for routine feed evaluation. In vitro methods provide less expensive and more rapid alternatives ${ }^{[17]}$. Digestibility may be directly determined in vivo or estimated by using in vitro procedures, which are cheaper and more convenient ${ }^{[5]}$.

There are number of in vitro techniques available to evaluate the nutritive value of feeds at relatively low cost such as in vitro gas production technique. The gas measuring technique was considered to be a routine method of feed evaluation after the work of Menke et al. ${ }^{[26]}$, where a high correlation between gas production in vitro and in vivo apparent digestibility was reported. Gas production techniques are based on the principle that anaerobic microbial digestion of carbohydrates releases gas (primarily $\mathrm{CO}_{2}$ and $\mathrm{CH}_{4}$ ) and $\mathrm{VFA}^{[21]}$.

Metabolizable energy represents that portion of the feed energy that can be utilized by the animal ${ }^{[1]}$. In vivo Organic Matter Digestibility (OMD) is defined as the proportion of feed OM apparently digested in the total digestive tract. Organic matter digestibility is a measure of energy available to ruminants and is used in protein evaluation system ${ }^{[18]}$. Menke and Steingass ${ }^{[27]}$ reported a strong correlation between Metabolizable Energy (ME) values measured in vivo and predicted from $24 \mathrm{~h}$ in vitro gas production and chemical composition of feeds. The in vitro gas production method has also been widely used to evaluate the energy value of several classes of feeds ${ }^{[15]}$, particularly straws ${ }^{[22]}$, agroindustrial by-products ${ }^{[19]}$, compound feeds ${ }^{[2]}$ and various tropical feeds ${ }^{[20]}$.

Corresponding Author: Taghizade Akbar, Department of Animal Science, Faculty of Agriculture, University of Tabriz, Iran Tel: +98-4113392029 Fax: +98-4113356004 
The objective of the present study was to determine apparent in vivo digestibility, gas production function and ME of some feedstuffs (corn grain, soybean meal, wheat bran and alfalfa).

\section{MATERIALS AND METHODS}

Experimental feeds: The samples of Corn Grain (CG), soybean meal (SBM), Wheat Bran (WB) and alfalfa (AA) were collected from dairy farm in northwestern of Iran. Alfalfa samples were not identified by maturity or variety. Samples of all test feeds for the gas production technique were milled through a $2.0 \mathrm{~mm}$ sieve and oven-dried at $80^{\circ} \mathrm{C}$ until constant weight and for chemical analyses they were milled through a $1.0 \mathrm{~mm}$ sieve.

Chemical analysis: Samples of feeds and feces were dried in an oven at $105^{\circ} \mathrm{C}$ for $24 \mathrm{~h}$ and the DM content calculated. Ground samples were analyzed for $\operatorname{ash}^{[4]}$. Determinations of $\mathrm{N}$ were conducted using the Kjeldahl method in an automated Kjelfoss apparatus (Foss Electric, Copenhagen, Denmark). Neutral-detergent fiber and ADF were determined by the detergent procedures of Van Soest et al. ${ }^{[36]}$. Acid-Detergent Insoluble Nitrogen (ADIN) was determined as nitrogen in Acid-detergent residue. Ether Extract (EE) was determined by extracting the sample with ether ${ }^{[4]}$.

Apparent in vivo digestibility: Initially apparent in vivo digestibility of alfalfa nutrients were obtained then digestibility of nutrients for the other test feeds were determined by difference method ${ }^{[8]}$. Sixteen Ghezel rams (43.9 $\pm 4 \mathrm{~kg}$ body weight) were used to measure the apparent in vivo digestibility of feeds. The animals were kept in metabolism stalls. Before the studies, all animals were sheared, dewormed. The alfalfa digestibility was measured in four rams fed alfalfa as ad libitum and other feeds digestibility were measured in twelve ram at the maintenance of body weight (38 g DM/ $\mathrm{W}^{0.75}$; NRC $\left.{ }^{[30]}\right)$ with a diet comprising $600 \mathrm{~g} \mathrm{~kg}^{-1}$ test feeds (CG, SBM and WB) and $400 \mathrm{~g} \mathrm{~kg}^{-1}$ basal feed (alfalfa). The diet was offered twice a day at 08:30 and 15:30 $\mathrm{h}$ in equal amounts after collecting the refusals. All animals were given free access to mineral salt lick and water throughout the experiment. Experimental period lasted for 21 days, comprising 14 days for adaptation to the diet and 7 days for total feces collection. Samples of feeds offered and feces were taken daily and bulked over the trial period. The dried and milled samples were used for the determination of dry matter, organic matter, crude protein, Neutral-detergent fiber and acid-detergent fiber. Digestibility of DM, OM, CP, NDF and ADF were then determined for each diet using equations given by Pond et al. ${ }^{[8]}$.

In vitro gas production: Samples (300 mg) were weighed into $100 \mathrm{~mL}$ serum vial. Mc Dougall ${ }^{[23]}$ buffer solution was prepared and placed in a water bath at $39^{\circ} \mathrm{C}$. Rumen liquor samples were obtained from the two wethers that were fed on a diet comprising (DM basis), $550 \mathrm{~g} \mathrm{~kg}^{-1}$ alfalfa hay, $400 \mathrm{~g} \mathrm{~kg}^{-1}$ barely grain, $50 \mathrm{~g} \mathrm{~kg}^{-1}$ wheat bran and $2 \mathrm{~g} \mathrm{~kg}^{-1}$ lime stone at maintenance level ${ }^{[30]}$. Rumen fluid was collected after the morning feeding. Rumen fluid was pumped with a manually operated vacuum pump and transferred into pre-warmed thermos flask, combined, filtered through four layers of cheesecloth and flushed with $\mathrm{CO}_{2}$. Each feed sample was incubated in triplicate with $20 \mathrm{~mL}$ of rumen liquor and buffer solution (1:2). Three vials containing only the rumen fluid/buffer solution and no feed sample was included with each test and the mean gas production value of these vials was termed the blank value. The vials were sealed immediately after loading and were affixed to a rotary shaker platform (lab-line instruments Inc Melors dark, USA) set at (120 rpm) housed in an incubator. Gas production was measured in each vial after 2, 4, 8, 12, 16, 24, 36, 48, 72 and $96 \mathrm{~h}$ of incubation using a water displacement apparatus $^{[12]}$.

Calculations and statistical analysis: Rate and extent of gas production was determined for each feed by fitting gas production data to the one component McDonald model: $\mathrm{Y}=\mathrm{A}\left(1-\mathrm{e}^{-\mathrm{ct}}\right)$, where $\mathrm{y}$ is the volume of gas produced at time $t, A$ the potential gas production $\left(\mathrm{mL} \mathrm{g}^{-1} \mathrm{DM}\right)$ and $\mathrm{c}$ the fractional rate of gas production. Parameters A and c were estimated by an iterative least square method using a non-linear regression procedure of the statistical analysis systems $^{[33]}$.

The metabolizable energy (MJ/kg DM) content of feeds and short chain fatty acid (SCFA) was calculated using equations of McDonald et al. ${ }^{[25]}$, Menke and Steingass ${ }^{[27]}$ and Menke et al. ${ }^{[26]}$ as:

for all feeds,

$\mathrm{ME}(\mathrm{MJ} / \mathrm{kg} \mathrm{DM})=0.016 \mathrm{DOMD}$

for forage feeds,

$\mathrm{ME}(\mathrm{MJ} / \mathrm{kg} \mathrm{DM})=2.20+0.136 \mathrm{GP}+0.057 \mathrm{CP}+$ $0.0029 \mathrm{CF}^{2}$

for concentrate feeds,

$\mathrm{ME}(\mathrm{MJ} / \mathrm{kg} \mathrm{DM})=1.06+0.157 \mathrm{GP}+0.084 \mathrm{CP}+$ $0.22 \mathrm{CF}-0.081 \mathrm{CA}$

for all feeds, 
$\operatorname{SCFA}(\mathrm{m} \mathrm{mol} / 200 \mathrm{mg} \mathrm{DM})=0.0222 \mathrm{GP}-0.00425$

where, DOMD is in vivo digestible organic matter in dry matter; GP is $24 \mathrm{~h}$ net gas production $(\mathrm{mL} / 200 \mathrm{mg}$ $\mathrm{DM})$; $\mathrm{CP}, \mathrm{CF}$ and $\mathrm{CA}$ are crude protein, crude fat and crude ash (\%DM), respectively.

Data on apparent in vivo digestibility and gas production parameters were subjected to one-way analysis of variance using the analysis of variation model (ANOVA) of SAS ${ }^{[33]}$. Multiple comparison tests used Duncan's multiple-range test ${ }^{[34]}$.

\section{RESULTS AND DISCUSSION}

Chemical composition: The chemical composition of test feeds is presented in the Table 1. The CP content of feeds ranged from $11.8 \%$ in corn grain to $49.2 \%$ in soybean meal. The NDF content of feeds ranged from $10 \%$ in corn grain to $53.3 \%$ in wheat bran. Corn grain contained substantially higher OM level than the other feeds.

Apparent in vivo digestibility: Values for digestibility of DM, CP, OM, NDF and ADF for each feedstuff are given in Table 2. There were differences between levels of disappearance for DM, CP, OM and NDF among feedstuffs $(\mathrm{p}<0.05)$. The lower and higher extent of DM digestibility was observed in AA (67\%) and CG (87\%), respectively $(\mathrm{p}<0.05)$. For $\mathrm{CP}$, the level of digestibility varied from $72 \%$ for AA to $98 \%$ for SBM. In AA, the digestibility of OM was lower than that of the other feedstuffs, whereas digestibility of OM from CG was higher than from the other feedstuffs. In addition, digestibility of NDF in CG was lower than in the other feedstuffs, whereas values for SBM were higher than the other feedstuffs $(\mathrm{p}<0.05)$.

In vitro gas production: There was a difference $(\mathrm{p}<0.05)$ in gas production among feeds (Table 3$)$. Potential gas production (A) and rates of gas production (c) differed $(\mathrm{p}<0.01)$ among feeds. The pattern of fermentation of test feeds was distinctly different, particularly at first times of incubation (Fig. 1). Wheat bran fermented faster and corn grain fermented slower than other test feeds.

Metabolizable energy (ME) and Short chain fatty acid (SCFA): According to studies that reported by Menke and Steingass ${ }^{[27]}$; Menke at al. ${ }^{[26]}$ and McDonald et al. ${ }^{[25]}$, SCFA and ME could be evaluated by $24 \mathrm{~h}$ in vitro gas production data and in vivo organic matter digestibility. These results are shown in Table 4.



Fig. 1: Pattern of in vitro gas production on incubation of test feeds in buffered rumen fluid

Table1: Chemical composition of the test feeds (\%DM)

\begin{tabular}{lcccc}
\hline & Feedstuffs & & & \\
Variable & Corn grain & Soybean meal & Wheat bran & Alfalfa \\
\hline DM & 92.5 & 94 & 92.9 & 94.9 \\
CP & 11.8 & 49.2 & 16.9 & 17 \\
EE & 6.1 & 4.2 & 5.4 & 3.3 \\
NDF & 10 & 44.9 & 53.3 & 49.9 \\
ADF & 6.2 & 13 & 15.8 & 40.3 \\
Hemicellulose & 3.8 & 31.9 & 37.5 & 9.6 \\
OM & 95.4 & 90.1 & 90.6 & 86.9 \\
ADIN & 0.41 & 0.55 & 0.07 & 0.12 \\
\hline
\end{tabular}

: Three samples analyzed for each feed. ADIN = Acid detergent insoluble nitrogen

Table 2: Apparent in vivo digestibility of DM, CP, OM, NDF and ADF in feedstuffs (\% of DM)

\begin{tabular}{|c|c|c|c|c|c|}
\hline \multirow[b]{2}{*}{ Feedstuffs } & \multicolumn{5}{|c|}{ Variable } \\
\hline & DM & $\mathrm{CP}$ & $\mathrm{OM}$ & NDF & $\mathrm{ADF}$ \\
\hline Corn grain & $87.9^{\mathrm{a}}$ & $74.7^{\mathrm{c}}$ & $88.9^{\mathrm{a}}$ & $48.6^{\mathrm{d}}$ & 49.7 \\
\hline Soybean meal & $83.8^{\mathrm{b}}$ & $98.3^{\mathrm{a}}$ & $85.7^{\mathrm{b}}$ & $80.0^{\mathrm{a}}$ & 48.2 \\
\hline Wheat bran & $74.2^{\mathrm{c}}$ & $79.6^{\mathrm{b}}$ & $75.6^{\mathrm{c}}$ & $64.6^{\mathrm{b}}$ & 49.5 \\
\hline Alfalfa & $67.0^{\mathrm{d}}$ & $72.8^{\mathrm{c}}$ & $68.1^{\mathrm{d}}$ & $58.0^{\mathrm{c}}$ & 54.8 \\
\hline SEM & 0.99 & 0.62 & 1.03 & 1.41 & 2.22 \\
\hline
\end{tabular}
$(\mathrm{p}<0.05)$. SEM $=$ Standard errors of means

Variation in test feeds chemical composition has been observed compared to other studies with test feeds $[1,28,31]$. The differences among chemical composition test feeds can be resulted due to variation in variety, cultivate, environmental condition and cut stage of feeds. Some of the feeds used in the current study were by-product feeds (such as soybean meal and wheat bran), which are created as a result of processing to extract human foods and therefore their composition varies depending on the composition of original plant material, method of processing and type of components extracted or removed ${ }^{[17]}$. 
American J. Animal \& Vety. Sci., 2 (4): 108-113, 2007

Table 3: In vitro gas production characteristics of feed samples incubated in buffered rumen fluid

\begin{tabular}{|c|c|c|c|c|c|c|c|c|c|c|c|c|}
\hline \multirow[b]{2}{*}{ Feeds } & \multicolumn{10}{|c|}{ Gas production $\left(\mathrm{mL} \mathrm{g}^{-1} \mathrm{DM}\right)$} & \multicolumn{2}{|c|}{ Gas production constants } \\
\hline & $2 \mathrm{~h}$ & $4 \mathrm{~h}$ & $8 \mathrm{~h}$ & $12 \mathrm{~h}$ & $16 \mathrm{~h}$ & $24 \mathrm{~h}$ & $36 \mathrm{~h}$ & $48 \mathrm{~h}$ & $72 \mathrm{~h}$ & $96 \mathrm{~h}$ & A & $\mathrm{c}$ \\
\hline$\overline{\mathrm{CG}}$ & $17^{\mathrm{c}}$ & $45^{\mathrm{d}}$ & $88^{\mathrm{d}}$ & $126^{\mathrm{d}}$ & $169^{\mathrm{c}}$ & $223^{\mathrm{b}}$ & $268^{b}$ & $297^{\mathrm{a}}$ & $313^{\mathrm{a}}$ & $320^{\mathrm{a}}$ & $326.56^{\mathrm{a}}$ & $0.048^{\mathrm{d}}$ \\
\hline SBM & $46^{\mathrm{a}}$ & $92^{\mathrm{b}}$ & $157^{\mathrm{b}}$ & $196^{\mathrm{b}}$ & $226^{\mathrm{b}}$ & $257^{\mathrm{a}}$ & $287^{\mathrm{ab}}$ & $304^{\mathrm{a}}$ & $319^{\mathrm{a}}$ & $333^{\mathrm{a}}$ & $319.64^{\mathrm{b}}$ & $0.071^{\mathrm{c}}$ \\
\hline WB & $55^{\mathrm{a}}$ & $121^{\mathrm{a}}$ & $191^{\mathrm{a}}$ & $223^{a}$ & $248^{\mathrm{a}}$ & $274^{\mathrm{a}}$ & $298^{\mathrm{a}}$ & $316^{\mathrm{a}}$ & $326^{\mathrm{a}}$ & $332^{\mathrm{a}}$ & $319.30^{\mathrm{c}}$ & $0.097^{\mathrm{a}}$ \\
\hline AA & $36^{\mathrm{b}}$ & $74^{\mathrm{c}}$ & $129^{\mathrm{c}}$ & $161^{\mathrm{c}}$ & $218^{\mathrm{b}}$ & $218^{\mathrm{b}}$ & $240^{c}$ & $252^{\mathrm{b}}$ & $258^{\mathrm{b}}$ & $260^{\mathrm{b}}$ & $257.65^{\mathrm{d}}$ & $0.081^{\mathrm{b}}$ \\
\hline $\operatorname{SEM}(n=3)$ & 2.96 & 2.83 & 4.48 & 5.23 & 5.58 & 6.71 & 7.99 & 8.21 & 8.63 & 9.16 & 0.0121 & 0.0004 \\
\hline
\end{tabular}

a, b, c, d: Means within a column with different subscripts differ $(\mathrm{p}<0.05)$. c: fractional rate of gas production $\left(\mathrm{h}^{-1}\right)$, A: potential gas production $\left(\mathrm{mL} \mathrm{g}^{-1} \mathrm{DM}\right) . \mathrm{CG}=$ Corn grain, $\mathrm{SBM}=$ Soybean meal, $\mathrm{WB}=$ Wheat bran, $\mathrm{AA}=$ Alfalfa

Table 4: Evaluated metabolizable energy by in vivo digestibility and gas production results $\left(\mathrm{MJ} \mathrm{kg}^{-1} \mathrm{DM}\right)$

\begin{tabular}{lllll}
\multicolumn{5}{c}{ gas production results (MJ kg } \\
& $\begin{array}{l}\text { According to in vivo } \\
\text { digestibility data }\end{array}$ & $\begin{array}{l}\text { According to in vitro } \\
\text { gas production data }\end{array}$ \\
\cline { 2 - 5 } Feedstuffs & DOMD & $\begin{array}{l}\mathrm{ME}(\mathrm{MJ} \\
\left.\mathrm{kg}^{-1} \mathrm{DM}\right)\end{array}$ & $\begin{array}{l}\mathrm{ME}(\mathrm{MJ} \\
\left.\mathrm{kg}^{-1} \mathrm{DM}\right)\end{array}$ & $\begin{array}{l}\text { SCFA (m moL } \\
/ 200 \mathrm{mg} \mathrm{DM})\end{array}$ \\
\hline Corn grain & 848 & 13.3 & 10.0 & 0.98 \\
Soybean meal & 771 & 12.1 & 13.4 & 1.13 \\
Wheat bran & 685 & 10.7 & 11.5 & 1.21 \\
Alfalfa & 591 & 9.2 & 7.9 & 0.96 \\
\hline
\end{tabular}

DOMD = In vivo digestible organic matter in dry matter $\left(\mathrm{g} \mathrm{kg}^{-1} \mathrm{DM}\right)$

The DM and CP digestibility values for CG, SBM, WB and AA were slightly lower than the values reported by Taghizadeh et al. ${ }^{[35]}$. This could be expected, because the mobile nylon bag technique gives an estimate of true digestibility ${ }^{[11,35,37]}$ rather than apparent digestibility, which is obtained using conventional in vivo digestibility determinations. The digestibility values of DM, CP, OM, NDF and ADF for SBM and WB were similar to reported values by Milis et al. ${ }^{[28]}$.

High DM and OM digestibility for BG can be predicted due to high non structural carbohydrates that supply available energy as ATP for microbial growth. Low digestibility OM in AA compared to CG was due to high containing of structural carbohydrates. The digestibility value of OM for SBM was different with reported values by $\mathrm{MAFF}^{[29]}$ and woods et al. ${ }^{[38]}$, but the digestibility value of $\mathrm{OM}$ for $\mathrm{CG}$ was similar to reported value by Cooper et al. ${ }^{[9]}$. The variation in digestibility values for test feeds compared to other study results can be related to differences in chemical composition, techniques of feed processing for SBM and WB and cut stage for AA.

The strong correlation between extent of gas production and chemical composition and the poor correlation between rate of gas production and chemical composition, is consistent with Nsahlai et al. ${ }^{[32]}$. Low gas yield for corn grain in initial incubation times compared to the other test feeds was resulted due to high content of slowly fermented carbohydrates in corn grain. The high level of wheat bran and soybean meal gas yield in several incubation times can be assumed that degradable nitrogen was not limiting microbial activity allowing the SBM and WB carbohydrate fractions be degraded according to their potential. Gasmi-Boubaker et al. ${ }^{[14]}$ reported the positive correlation between $\mathrm{CP}$ and gas production at $24 \mathrm{~h}$ in Mediterranean browse species. Getachew et al. ${ }^{[17]}$ reported that feed CP level was negatively correlated with gas production. However other studies with different types of feeds (i.e., CP ranging from 32 to 487 $\mathrm{g} \mathrm{kg}^{-1} \mathrm{DM}$; Blümmel et al. ${ }^{[7]}$ ) have shown no effect of $\mathrm{CP}$ level on gas production.

The lower extent of gas production occurred in alfalfa, also it had the lower fractional rate of gas production (c), potential gas production (A). These species were high in cell wall and lignin, which have been widely reported to decrease rate and extent of gas production $^{[13,16]}$. This suppressing effect probably results from a reduction in attachment of ruminal microbes to feed particles ${ }^{[24]}$.

The gas production values for corn grain, soybean meal and alfalfa were different those reported by Getachew et al. ${ }^{[16]}$, which could be due to differences in the chemical composition of the feeds.

The high positive correlation among GP, DM and OM digestibility has been reported ${ }^{[10]}$. Al-Masri ${ }^{[3]}$ reported a very highly significant $(\mathrm{p}<0.0001)$ relationship between gas production and the true and apparent fermented organic matter.

According to in vivo organic matter digestibility data, the ME values ranged from 9.2 in alfalfa to 13.3 MJ $\mathrm{kg}^{-1} \mathrm{DM}$ in corn grain. This could be expected, because the corn grain had the highest organic matter digestibility among the other test feeds. On the contrary, alfalfa had the lower $(\mathrm{p}<0.05)$ organic matter digestibility because of its high containing of NDF and ADF. The negative effect of NDF on organic matter digestibility and metabolizable energy is in close agreement with al-Masri ${ }^{[3]}$. $\mathrm{NRC}^{[31]}$ was reported that ME for corn grain, soybean meal, wheat bran and alfalfa were 13.04, 13.83, 10.65 and $8.19 \mathrm{MJ} \mathrm{kg}^{-1} \mathrm{DM}$, respectively. The difference between the $\mathrm{NRC}^{[31]}$ data and current study for ME values of test feeds can be predicted due to variation in estimated assay, nutrient 
composition of feeds and processing techniques. According to in vitro gas production data, the $\mathrm{ME}$ values ranged from 7.9 in alfalfa to $13.4 \mathrm{MJ} \mathrm{kg}^{-1} \mathrm{DM}$ in soybean meal.

The difference between two methods' results, especially for $\mathrm{CG}$, arises from their kinetic of fermentation and rate of gas production in in vitro gas production technique. Fermentative gas is produced mainly when feedstuffs are fermented to acetate and butyrate, with propionate yielding gas only due to buffering of the acid. Thus feeds that produce high amounts of propionate yield lower gas volumes ${ }^{[6]}$. Low determination of corn grain's metabolizable energy in gas production method can be resulted from its low rate of gas production and extent of gas production at $24 \mathrm{~h}$. The high non-fiber carbohydrate content of corn grain leads to proportionally higher propionate production, thereby reducing the acetate to propionate ratio ${ }^{[17]}$.

Highly significant correlation has been observed between SCFA and gas production ${ }^{[6]}$. The molar proportions of different SCFA (acetate, propionate and butyrate) produced is dependent on the type of substrate $^{[6]}$.

Protein degradation leads to a proportionally smaller amount of SCFA. The extent of SCFA production from proteins is dependent upon on the amino acid composition of the feeds and the extent of rumen deamination of these amino acids. The carbon skeleton arising from deamination gives rise to a variety of VFA. For example, fermentation of glycine can lead to ammonia and acetic acid without the release of $\mathrm{CO}_{2}$ and that of leucine, isoleucine and valine to isovaleric acid, 2-methylbutyric acid and isobutyric acids, respectively ${ }^{[17]}$.

\section{REFERENCES}

1. Agricultural and Food Research Council (AFRC), 1993. Energy and protein requirements of ruminants. CAB International, Wallingford, Oxon, England.

2. Aiple, K.P., H. Steingass and W. Drochner, 1996. Prediction of the net energy content of raw materials and compound feeds for ruminants by different laboratory methods. Arch. Anim. Nutr., 49: 213-220.

3. Al-Masri, M.R., 2003. An in vitro evaluation of some unconventional ruminant feeds in terms of the organic matter digestibility, energy and microbial biomass. Trop. Anim. Health and Prod., 35 (2): 155-167.
4. AOAC. 2005. Official Methods of Analysis of AOAC international. AOAC international. Maryland, USA.

5. Aregheore, E.M., 2000. Chemical composition and nutritive value of some tropical by-product feedstuffs for small ruminants-in vivo and in vitro digestibility. Anim. Feed Sci. Technol., 85: 99-109.

6. Beuvink, J.M.W. and S.F. Spoelstra, 1992. Interactions between substrate, fermentation end products, buffering systems and gas production upon fermentation of different carbohydrates by mixed rumen microorganisms in vitro. Appl. Microbiol. Biotechnol., 37: 505-509.

7. Blümmel, M., K.P. Aiple, H. Steingass and K. Becker, 1999. A note on the stoichiometrical relationship of short chain fatty acid production and gas evolution in vitro in feedsstuffs of widely differing quality. J. Anim. Physiol. Anim. Nutr., 81: 157-167.

8. Pond, W.G., D.C. church and K.R. Pond, 1995. Basic Animal nutrition and feeding. John Wiley, New York.

9. Cooper, R.J., C.T. Milton, T.J. Klopfenstein, T.L. Scott, C.B. Wilson and R.A. Mass, 2002. Effect of corn processing on starch digestion and bacterial crude protein flow in finishing cattle. J. Anim. Sci. 80: 797-804.

10. Datt, C. and G. Singh, 1995. Effect of protein supplementation on in vitro digestibility and gas production of wheat straw. Indian J. Dairy Sci., 48: 357-361.

11. De Boer, G., J.J. Murphy and J.J. Kennelly, 1987. Mobile nylon bag for estimating intestinal availability of rumen undegradable protein. J. Dairy Sci. 70: 977-982.

12. Fedorak, P.M. and S.E. Hrudey, 1983. A Simple apparatus for measuring gas production by methanogenic cultuvesin serum bottles. Environ. Technol. Lett., 4: 425-435.

13. Frutos, P., G. Hervas, G. Ramos, F.J. Giraldez and A.R. Montecon, 2002. Condensed tannin content of several shrub species from a mountain area in northern Spain and its relationship to various indicators of nutritive value. Anim. Feed Sci. Technol., 95: 215-226.

14. Gasmi-Boubaker, A., C. Kayouli and A. Buldgen, 2005. In vitro gas production and its relationship to in situ disappearance and chemical composition of some Mediterranean browse species. Anim. Feed Sci. Technol., 123-124: 303-311.

15. Getachew, G., M. Blummel, H.P.S. Makkar and K. Becher, 1998. In vitro gas measuring technique for assessment of nutritional quality of feeds: A review. Anim. Feed Sci. Technol., 72: 261-281. 
16. Getachew, G., H.P.S. Makkar and K. Becker, 2000. Effect of polyethylene glycol on in vitro degradability and microbial protein synthesis from tannin-rich browse and herbaceous legumes. B. J. Nutr., 84: 73-83.

17. Getachew, G., P.H. Robinson, E.J. De Peters and S.J. Taylor, 2004. Relationships between chemical composition, dry matter degradation and in vitro gas production of several ruminants feed. Anim. Feed Sci. Technol., 111: 57-71.

18. Gosselink, J.M.J., J.P. Dulphy, C. Poncet, M. Jailler, S. Tamminga and J.W. Cone, 2004. Prediction of forage digestibility in ruminants using in situ and in vitro techniques. Anim. Feed Sci. Technol., 115: 227-246.

19. Krishna, G. and K.D. Gunther, 1987. The usability of Hohenheim gas test for evaluating in vitro organic matter digestibility and protein degradability at rumen level of some agroindustrial by-products. Landwirtschaftliche Forshung, 40: 281-286.

20. Krishnamoorthy, U., H. Soller, H. Steingass and K.H. Menke, 1995. Energy and protein evaluation of tropical feedstuffs for whole tract and ruminal digestion by chemical analysis and rumen inoculum studies in vitro. Anim. Feed Sci. Technol., 52: 177-188.

21. Lanzas, C., D.G. Fox and A.N. Pell, 2007. Digestion kinetics of dried cereal grain. Anim. Feed Sci. Technol., 136: 265-280.

22. Makkar, H.P.S., E.M. Aregheore and K. Becker, 1999. Effect of saponins and plant extracts containing saponins on the recovery of ammonia during urea-ammoniation of wheat straw and fermentation kinetics of the treated straw. J. Agric. Sci., Cambridge, 132: 313-321.

23. McDougall, E.I. 1948. The composition and output of sheep in saliva. Bio Chem. J., 43: 99-109.

24. McAllister, T.A., H.D. Bae, G.A. Jones and L.J. Cheng, 1994. Microbial attachment and feed digestion in the rumen. J. Dairy Sci. 72: 3004-3018.

25. McDonald, P., R.A. Edwards, J.F.D. Greenhalgh and C.A. Morgan, 1995. Animal Nutrition. Long Man Company, London.

26. Menke, K.H., L. Raab, A. Salewski, H. Steingass, D. Fritz and W. Schneider, 1979. The estimation of the digestibility and metabolizable energy content of ruminant feeding stuffs from the gas production when they are incubated with rumen liquor. J. Agric. Sci., 93: 217-222.
27. Menke, K.H. and H. Steingass, 1988. Estimation of the energetic feed value obtained from chemical analysis and gas production using rumen fluid. Anim. Res. Dev., 28: 7-55.

28. Milis, Ch., D. Liamadis, Ch. Karatzias and Z. Abas, 2007. Nitrogen in vivo digestibility and in situ degradability data for estimation of lower tract $\mathrm{N}$ digestibility with or with out coreection for microbial contamination. J. Small Ruminat Res., 71: 205-214.

29. Ministry of Agriculture Fisheries and Food (MAFF) 1990. Standing Committee on Tables of Feed Composition, UK Tables of Nutritive Value.

30. National Research Council. 1985. Nutrient Requirements of Sheep. 6th Rev. Edn. Natl. Acad. Sci., Washington, DC.

31. National Research Council. 2001. Nutrient Requirements of Dairy Cattle. 7th Rev. Edn. Natl. Acad. Sci., Washington, DC.

32. Nsahlai, I.V., D.E.K.A. Siaw and P.O. Osuji, 1994. The relationship between gas production and chemical composition of 23 browses of the genus Sesbania. J. Sci. Food Agric., 65: 13-20.

33. SAS, 1999. Version release 8/0. SAS Institute Inc., Cary, NC, USA.

34. Snedecor, G.W. and W.G. Cochran, 1980. Statistical Methods. Iowa State University Press, Ames, IA, USA.

35. Taghizadeh, A., M. Danesh mesgaran, F. Eftekhar Shahroodi and K. Stanford, 2005. Digestion of feed amino acids in rumen and intestine of steers measured using a mobile nylon bag technique. J. Dairy Sci., 88: 1714-1807.

36. Van Soest, P.J., J.B. Robertson and B.A. Levvis, 1991. Methods for dietary fiber, neutral detergent fiber and non starch polysaccharides in ration to animal nutrition. J. Anim. Sci., 74: 3583-3597.

37. Von Keyserlingk, M.A.G., M.L. Swift, R. Puchala and J.A. Shelford, 1996. Degradability characteristics of dry matter and crude protein of forages in ruminant. Anim. Feed Sci. Technol., 57: 291-311.

38. Woods, V.B., F.P. O'Mara and A.P. Moloney, 2003. The nutritive value of concentrate feedstuffs for ruminant animals. Part $\mathrm{I}$ : in situ ruminal degradability of dry matter and organic matter. Anim. Feed Sci. Technol., 110: 111-130. 